\title{
Soviet space effort is strictly for the cash, not the glory
}

According to TASS, the flight programme of Soyuz-32 - launched on 25 February-includes docking with the Salyut-6 orbiting station and checking it for a possible further mission aboard the station. This suggests that the Soviet planners are anxious to get their last kopek's-worth out of Salyut-6, which has already been in orbit for almost 18 months.

Although the finances of the Soviet space programme are never published, current Party doctrine stresses that all branches of science should direct their research towards the practical needs of the national economy. The economic pay-off from the Soviet space programme was therefore the keynote of a press conference in Moscow last month given by chief Training Officer Vladimir A. Shatalov and cosmonaut Vladimir Kovalenkov.

According to Shatalov, "the greatest economic impact, the greatest benefit so far can be derived from research in near-Earth space and in the operation of orbital stations". This, he said, would remain the basis of the Soviet space programme for the next few years, because such questions "really do bring considerable, obvious benefits even now".

Illustrating such benefits, Kovalenkov mentioned observations from orbit of dust storms and meteorogical and oceanological processes. When observations of the oceans began, he and his fellow-cosmonauts were not told what they were supposed to be observing. They had to work out by trial and error such practical matters as the best porthole to use in relation to the Sun's position. After some time, he said, it was possible to understand "to some extent" the ocean currents, and hence to identify resources of phytoand zooplankton-to the ultimate benefit of the Soviet fishing fleet.

Observations from orbit of ocean vortices, Kovalenkov added, had led to an oceanological expedition to the Atlantic last summer. From subsequent reports, it appears that this expedition established the existence of isolated closed spiral currents, with diameter up to 200 miles. However these are predominantly in the Bermuda Triangle area, and the unbiassed observer should remember that the Soviets, being good dialectical materialists, are at pains to find a physical explanation of the supposed Bermuda Triangle disappearances.

The observation of such processes from space will be a maor task of the first Soviet unmanned oceanographic satellite, Kosmos-1076, launched on 12 February. Soviet space planners have always stressed the great potential of unmanned craft and probes. The US Apollo moonflights, for example, were presented in the Soviet media as a waste of funds. The Luna spacecrafts and lunokhod rovers, it was stressed, could do all that a manned Soviet mission might do, at half the cost. Kovalenok's remarks would suggest, however, that without the recent longterm manned Salyut missions, the programme of the unmanned Kosmos-1074 might well have been a somewhat hitand-miss affair.

Earthquakes are another Soviet concern. A team at the State Nature Centre are using photographs from the Salyut missions to predict earthquakes in the Soviet seismic zones. A spokesman from the centre explained recently on Moscow radio that the seismic zones were first observed visually by Yurii Gagarin. Since some $15 \%$ of the terrain of the USSR is seismically active, while some $30 \%$ of the population live in these areas, earthquake prediction from satellite observations, he said, could produce "tremendous" savings in construction costs. Preliminary work along these lines was begun by the Salyut- 6 crews last year.

Even the exotic triple $\mathrm{Cd}-\mathrm{Hg}-\mathrm{Te}$ semiconductor crystals produced about Salyut-6 in the joint Soviet-Polish "Syrena" experiment have their practical use. They have been handed over to the Polish Institute of Mining Safety, to be used in producing infrared-sensitive pyrometers.

Salyut, it would therefore seem, is paying its way. Indeed, Shatalov himself admitted as much in a recent interview with the Bulgarian daily Otechestven Front. Much of his state-

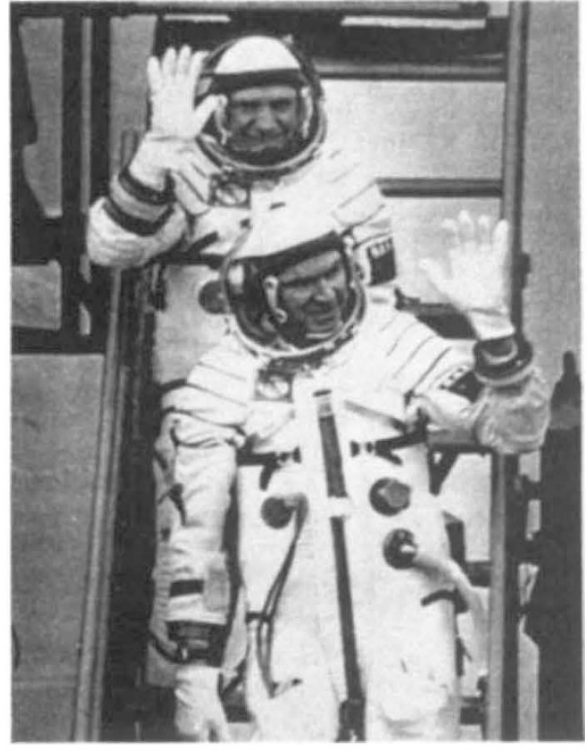

Soyuz-32 send off: Cosmonauts Lyakhov (top) and Ryumin before Sunday's launch.

ment was, naturally, devoted to the training of the Bulgarian cosmonaut candidates, in the Interkosmos programme, but in referring to the work of the Salyut crews "including the international ones" carrying out extremely valuable observations for the national economy, he implied that, in his opinion, from now on the programme would be operating essentially on a break-even basis.

Looking to the more distant future, $\mathrm{Mr}$ Shatalov noted that, with bigger spacecraft, there would be a stricter division of crews into scientific and operational personnel. This would cut considerably the training demands on the individual members of the crew who would now need to qualify only as scientists or, alternatively, as spaceship operatives. Ultimately, he said, a whole "Aeroflot-type" back-up organisation would have to be set up as well, to handle the terrestrial processing of the flights.

Vera Rich

\section{Space shuttle may be six months late}

A study group of the US National Academy of Sciences predicts that engine problems mean the space shuttle's first flight, officially planned by NASA for November this year, is now unlikely to take place until April 1980.

In a report prepared at the request of the Senate committee on science, space and technology, the group says it is particularly concerned that the engine that will actually fly in the space shuttle will not be the same configuration as that currently being tested, and that, in the circumstances, plans to perform flight certification tests on the engine, which will be used among other things to help launch the European Space Agency's Spacelab, are premature.

"The only rational option, for safety's sake, is to reschedule the formal flight certification until the configuration is fixed," Professor Eugene E. Covert, professor of aeronautics and astronautics at the Massachusetts Institute of Technology and chairman of the National Research Council group which prepared the report, said last week. 